\title{
Composition of Sugars in Honey Produced in the South-South and South-West Regions of Nigeria
}

\section{Olajumoke Omobola Lawal1 ${ }^{1}$, Ekpe Onot Obolo1, Stella Celestine Bassey ${ }^{1}$, Okey Ogbaka Obeten ${ }^{1}$}

${ }^{1}$ Human Nutrition and Dietetics Unit, Department of Biochemistry, University of Calabar, P.M.B. 1115 Calabar. Nigeria

\begin{abstract}
Six samples of honey from two states in Nigeria, Cross River and Oyo were investigated. (Igoli in Ogoja, farm bred and wild species from Obudu, Agoi Ibami, Eruwa and Iseyin) were analysed for their sugar components, Hydroxymethyl furfural (HMF), free acidity and electrical conductivity. Honey is composed of various sugars but the dominant sugars are two monosaccharide, fructose and glucose which are also reducing sugars. Honey is used for various purposes including medicinal, cosmetics, in the food industry, bakery and confectionary. The sugar contents were analysed using the HPLC with refractive Index (RI). The European Commission procedures were used to analyse HMF and electrical conductivity, while free acidity was analysed by AOAC methods (1999). The results of the analysis showed that although fructose and glucose were predominant in all the samples, only two samples, Igoli in Ogoja and Obudu farm bred met the Codex Alimentarius standard for fructose and glucose at $60 \mathrm{~g} / 100 \mathrm{~g}$. Fructose values $(\mathrm{g} / 100 \mathrm{~g})$ reported for Igoli in Ogoja, Obudu farm, Agoi Ibami, Obudu wild, Eruwa and Iseyin were $34.92 \pm 0.12,36.45 \pm 0.14,30.50 \pm 0.06,28.45 \pm 0.09,33.40 \pm 0.17$, and $30.45 \pm 0.09$ respectively. Sucrose in all the honey samples met the Codex Alimentarius standard of $<5 \mathrm{~g} / 100 \mathrm{~g}$ limit. Fructose/glucose ratio for all the samples was greater than 1 which indicated slower crystallization of all the honey samples. Values of free acidity ranged from $11.57 \pm 0.07$ to $18.60 \pm 0.10 \mathrm{meq} / \mathrm{kg}$, which were lower than the $50 \mathrm{meq} / \mathrm{kg}$ limit set by the Council of the European Union showing the absence of undesirable fermentation. HMF concentration in the samples all met the International optimum value of $40 \mathrm{mg} / \mathrm{kg}$ reported by European Union and $80 \mathrm{mg} / \mathrm{kg}$ for honey from the tropics. Electrical conductivity of the samples varied from $0.41 \pm 0.01$ to $0.63 \pm 0.00 \mathrm{mS} / \mathrm{cm}$. The results showed that the honey samples sold locally in Nigeria meet the required international standards for honey.
\end{abstract}

Keywords: Sugars, Hydroxymethyl Furfural, Free Acidity, Electrical Conductivity

\section{Introduction:}

Honey (Apis mellofera) is a sweet, thick, supersaturated sugar solution produced by honey bees from plant nectars, plant secretion and excretions of plant-suckling insects of the living parts of plants (Codex Alimentation, 2001). It is one of the known natural sources of sweetness and energy for man. Honey is composed mainly of disaccharides which contain two monosaccharaides, glucose and fructose, with a percentage of water and other group of substances (Kamal and Kleen; 2010). Small quantities of other sugars are also present, in the form of other disaccharides, trisaccharides and oligosaccharides which are formed during the ripening and storage effects of bee enzymes and acids of honey (Ball, 2007). Chemical compositions of honey differ depending on the plant species on which the bees forage, the climatic conditions and other factors (Buba et al., 2013). The very concentrated solution of several sugars produce the characteristic physical properties of honey like high viscosity, high density, graduation tendencies, tendency to absorb water from the atmosphere and immunity from some types of spoilage (White and Doner, 1980). Honey has been used as food and for medicinal purposes since stone age. It's medicinal properties as remedy for burns, scars, wound healing and ulcers have been established. It is also used as a sweetening agent for children's drugs, treatment of sore throat, cough and hay fever (Adenekan et al., 2012; Aloisi, 2010; Fasasi, 2010). The wax from bees is used in food processing industries as additives, making of chewing gums and in cosmetic industries for making lip balm, lip gloss, hand creams, moisturizers and many others (Ezekiel et al., 2013; Dike and Onwuka, 2016).

Honey has been reported to have an inhibitory effect on around 60 species of bacteria, some species of

This article is published under the terms of the Creative Commons Attribution License 4.0

Author(s) retain the copyright of this article. Publication rights with Alkhaer Publications.

Published at: http://www.ijsciences.com/pub/issue/2017-08/

DOI: 10.18483/ijSci.1410; Online ISSN: 2305-3925; Print ISSN: 2410-4477 
fungi and viruses Human Metabolomic Databases (2009). It has antioxidant, anti-inflammatory and anti-microbial properties (Alvarez-Suarez et al., 2014). Its antioxidant capacity is due to its wide range of compounds which include peptides, organic acids, phenolic enzymes and Maillard reaction products (Eteraf-Oskouei and Najafi, 2013). Honey is consumed for its high nutritive value and effects on human health. Among the sugars in honey include sucrose, turanose, nigerose, maltose, kejibiose, with traces of trehalose, isomaltose and raffinose (Cantarelli et al., 2008). Kejibiose is a reducing sugar which was accidentally discovered by scientists in Germany. Nigerose is an unfermented sugar obtained by partial hydrolysis of nigeran. It is a product of the caramelization of glucose (Human Metabolomic Database. 2009). Fructose and glucose are the dominant sugars in honey (Chaker et al., 2016; ElSahaimy et al., 2015; Fasasi, 2012; Kamal and Klein, 2010; White and Doner, 1980). Hydroxymethyl furfural (HMF), another component of honey, indicates freshness of honey and good conservation. It is a product of the decomposition of fructose and it is found in trace amounts in honey (Buba et al., 2013; Fasasi, 2012; Canterelli et al., 2008). HMF of honey can be increased by various factors including storage temperature, heat, moisture content and acidity (Buba et al., 2013). The Codex Alimentarius Commission recommended the optimal value for HMF in honey as $40 \mathrm{mg} / \mathrm{kg}$ for the European Union and $80 \mathrm{mg} / \mathrm{kg}$ for the tropics (Bogdanov, 2009). Acidity of honey is directly related to its floral sources and in combination with its electrical conductivity, can affect its quality and classification (Yadata, 2014). Electrical conductivity is the indication of ionizable acids and compounds in aqueous solution (Chaker, 2016). Bee-keeping have been the way of life of the people of Cross River and Oyo States of Nigeria, although it had not been on a commercial scale until recently when honey became an alternative for table sugar and also a possible foreign exchange commodity.

This study determines the various sugar components, HMF, free acidity and electrical conductivity of honey from the northern and central senatorial districts of Cross River State and central senatorial district of Oyo State in Nigeria.

\section{Materials and Methods}

The honey samples were purchased from farmers from Igoli in Ogoja, Obudu (farm bred and wild), Agoi Ibami, Eruwa and Iseyin, stored in a dark cupboard at room temperature until needed for the analysis.

\section{Analysis of sugars}

The method Bogdanon and Baumann (1988) determines fructose, glucose, sucrose, furanose and maltose in honey, for which precision data were required. It can also be used for the quantification of other saccharides such as melezitose, erlose, isomaltose, raffinose and others as described by Bogdanon and Baumann (1988). Sugar content was determined by High Performance Liquid Chromatography (HPLC ) with Refractive Index(RI) detector and analytical steel column in amine modified silica gel of 5-7micrometer particle size and $250 \times 4.6 \mathrm{~mm}$ diameter. A measured amount $(5 \mathrm{~g})$ of honey was dissolved in $40 \mathrm{ml}$ of water, $25 \mathrm{ml}$ methanol was pipetted into a $100 \mathrm{ml}$ volumetric flask and the honey solution transferred into the flask. This was then filled to the mark with water. Thereafter, $2.0 \mathrm{~g}$ of fructose, $1.5 \mathrm{~g}$ of glucose, $0.25 \mathrm{~g}$ of sucrose and $0.15 \mathrm{~g}$ each of turanose, maltose and all other sugars analysed were used as standards. The solution was poured through a membrane filter and collected in sample vials (Bognadov et al., 1997; Bogdanov and Baumann, 1988). All sugars were purchased from Merck (Switzerland) except turanose and erlose (Senn Chemicals, Dielsdorf, Switzerland).

\section{Hydromethyl furfural (HMF) analysis}

HMF was determined according to the European Commission method of analysis (Bogdanov et al., 1997). Twenty grams (20g) of the sample was dissolved in $100 \mathrm{ml}$ milli-Q water, filtered through a $0.22 \mathrm{~mL}$ nylon filter into an HPLC vial, capped and injected with 20microlitre loop into the HPLC. HMF concentration in the honey was calculated by comparing the peak area to that of the standards taking the solution into account (Bogdanon et al., 1997). There is a linear relationship between the concentration and the peak area and the results were expressed in $\mathrm{mg} / \mathrm{kg}$ honey.

\section{Free Acidity and Electrical Conductivity analyses}

Free acidity was determined by titrimetric method. The addition of $0.10 \mathrm{~N}$ sodium hydroxide $(\mathrm{NaOH})$ was stopped at $\mathrm{pH} 8.3$ (AOAC, 1999). While electrical conductivity was measured on $20 \%$ (g/g by dry weight) honey solution in carbon dioxide free deionised distilled water at $20^{\circ} \mathrm{C}$ Bognadov et al., (1997) and expressed in millisiemens per $\mathrm{cm}$ ( $\mathrm{mS} / \mathrm{cm})$. 
Results

TABLE 1: Comparison of different forms of sugars obtained from CRS and Oyo States

\begin{tabular}{|c|c|c|c|c|c|c|}
\hline Sugars g/100g & $\begin{array}{l}\text { Igoli Ogoja } \\
\text { (CRS) }\end{array}$ & $\begin{array}{l}\text { Obudu farm } \\
\text { (CRS) }\end{array}$ & $\begin{array}{l}\text { Agoi Ibami } \\
\text { (CRS) }\end{array}$ & $\begin{array}{l}\text { Obudu wild } \\
\text { (CRS) }\end{array}$ & $\begin{array}{c}\text { Eruwa } \\
\text { (Oyo State) }\end{array}$ & $\begin{array}{c}\text { Iseyin } \\
\text { (Oyo State) }\end{array}$ \\
\hline \multirow[t]{2}{*}{ Fructose } & 34.92 & 36.45 & 30.50 & 28.45 & 33.40 & 30.45 \\
\hline & \pm 0.12 & \pm 0.14 & \pm 0.06 & \pm 0.09 & \pm 0.17 & \pm 0.09 \\
\hline \multirow[t]{2}{*}{ Glucose } & 27.50 & 29.30 & 23.07 & 20.20 & 24.13 & 22.60 \\
\hline & \pm 0.17 & \pm 0.06 & \pm 0.03 & \pm 0.06 & 1.08 & \pm 0.06 \\
\hline \multirow[t]{2}{*}{ Sucrose } & 0.73 & 0.70 & 1.20 & \pm 0.73 & 1.07 & 1.20 \\
\hline & \pm 0.03 & \pm 0.00 & \pm 0.06 & \pm 0.03 & \pm 0.09 & \pm 0.06 \\
\hline \multirow[t]{2}{*}{ Turanose } & 2.40 & 2.38 & 2.12 & 1.87 & 2.20 & 2.38 \\
\hline & \pm 0.06 & \pm 0.09 & \pm 0.11 & \pm 0.03 & \pm 0.06 & \pm 0.04 \\
\hline \multirow[t]{2}{*}{ Nigerose } & 2.07 & 2.13 & 1.80 & 1.73 & 2.10 & 2.21 \\
\hline & \pm 0.13 & \pm 0.03 & \pm 0.00 & \pm 0.03 & \pm 0.06 & \pm 0.00 \\
\hline \multirow[t]{2}{*}{ Maltose } & 1.50 & 1.70 & 1.33 & 1.33 & 1.73 & 1.63 \\
\hline & \pm 0.01 & \pm 0.00 & \pm 0.03 & \pm 0.07 & \pm 0.03 & \pm 0.03 \\
\hline \multirow[t]{2}{*}{ Kojibiose } & 1.00 & 1.03 & 0.80 & 0.33 & 0.87 & 1.17 \\
\hline & \pm 0.10 & \pm 0.07 & \pm 0.00 & \pm 0.03 & \pm 0.03 & \pm 0.07 \\
\hline \multirow[t]{2}{*}{ Tretialose } & 0.43 & 0.60 & 0.53 & 0.60 & 0.43 & 0.60 \\
\hline & \pm 0.07 & \pm 0.00 & \pm 0.07 & \pm 0.06 & \pm 0.07 & \pm 0.00 \\
\hline \multirow[t]{2}{*}{ Isomaltose } & 0.30 & 0.47 & 0.40 & 0.43 & 0.70 & 0.50 \\
\hline & \pm 0.00 & \pm 0.07 & \pm 0.00 & \pm 0.07 & \pm 0.00 & \pm 0.00 \\
\hline \multirow[t]{2}{*}{ Erlose } & 0.47 & 0.43 & 0.37 & 0.37 & 0.23 & 0.10 \\
\hline & \pm 0.03 & \pm 0.03 & \pm 0.03 & \pm 0.03 & \pm 0.07 & \pm 0.00 \\
\hline \multirow[t]{2}{*}{ Melezitose } & 0.27 & 0.30 & 0.30 & 0.23 & 0.43 & 0.60 \\
\hline & \pm 0.03 & \pm 0.00 & \pm 0.00 & \pm 0.03 & 0.17 & \pm 0.06 \\
\hline \multirow[t]{2}{*}{ Raffinose } & 0.30 & 0.40 & 0.47 & 0.37 & 0.67 & 0.70 \\
\hline & \pm 0.00 & \pm 0.00 & \pm 0.03 & \pm 0.03 & \pm 0.03 & \pm 0.00 \\
\hline \multirow[t]{2}{*}{ Gentiobiose } & 0.43 & 0.33 & 0.43 & 0.30 & 0.60 & 0.47 \\
\hline & \pm 0.03 & \pm 0.07 & \pm 0.07 & 0.10 & \pm 0.00 & \pm 0.03 \\
\hline \multirow[t]{2}{*}{ Melibiose } & 0.00 & 0.00 & 0.00 & 0.00 & 0.20 & 0.40 \\
\hline & \pm 0.00 & \pm 0.00 & \pm 0.00 & \pm 0.00 & \pm 0.00 & \pm 0.00 \\
\hline \multirow[t]{2}{*}{ Maltotriose } & 0.20 & 0.13 & 0.17 & 0.23 & 0.53 & 0.37 \\
\hline & \pm 0.00 & \pm 0.03 & \pm 0.03 & \pm 0.07 & \pm 0.07 & \pm 0.07 \\
\hline \multirow[t]{2}{*}{ Fruct/Glu Ratio } & 1.27 & 1.24 & 1.32 & 1.41 & 1.39 & 1.35 \\
\hline & \pm 0.01 & \pm 0.01 & \pm 0.00 & \pm 0.00 & \pm 0.07 & \pm 0.01 \\
\hline \multirow[t]{2}{*}{ Fruct + Glu. } & 62.42 & 65.75 & 53.57 & 48.55 & 57.53 & 53.05 \\
\hline & \pm 0.29 & \pm 0.09 & \pm 0.03 & \pm 0.08 & 0.94 & \pm 0.03 \\
\hline \multirow[t]{2}{*}{ Total Sugars } & 72.66 & 77.11 & 64.72 & 58.59 & 70.86 & 67.00 \\
\hline & \pm 1.00 & \pm 0.30 & \pm 0.40 & \pm 0.14 & \pm 0.46 & \pm 0.46 \\
\hline
\end{tabular}


TABLE 2: Comparison of physical properties of sugars obtained from Cross River and Oyo Staes

$\begin{array}{lcccccc} & \begin{array}{c}\text { Igoli Ogoja } \\ \text { (CRS) }\end{array} & \begin{array}{c}\text { Obudu farm } \\ \text { (CRS) }\end{array} & \begin{array}{c}\text { Agoi Ibami } \\ \text { (CRS) }\end{array} & \begin{array}{c}\text { Obudu wild } \\ \text { (CRS) }\end{array} & \begin{array}{c}\text { Eruwa } \\ \text { (Oyo State) }\end{array} & \begin{array}{c}\text { Iseyin } \\ \text { (Oyo State) }\end{array} \\ \text { HMF mg/kg } & 15.37 & 18.90 & 21.87 & 12.77 & 16.07 & 62.60 \\ & \pm 0.18 & \pm 0.01 & \pm 0.38 & \pm 0.29 & \pm 0.15 & \pm 0.71 \\ \text { Free acidity } & 12.83 & 11.57 & 12.87 & 11.77 & 18.60 & 18.20 \\ \text { meq/kg } & \pm 0.24 & \pm 0.07 & \pm 0.18 & \pm 0.18 & \pm 0.10 & \pm 0.51 \\ \text { Elect. Cond. } & 0.41 & 0.45 & 0.42 & 0.45 & 0.61 & 0.63 \\ \text { mS/cm } & \pm 0.01 & \pm 0.01 & \pm 0.01 & \pm 0.01 & \pm 0.01 & \pm 0.00\end{array}$

Values are expressed as mean

Similar symbols have homogenous mean values \pm SEM, $\mathrm{n}=3$.

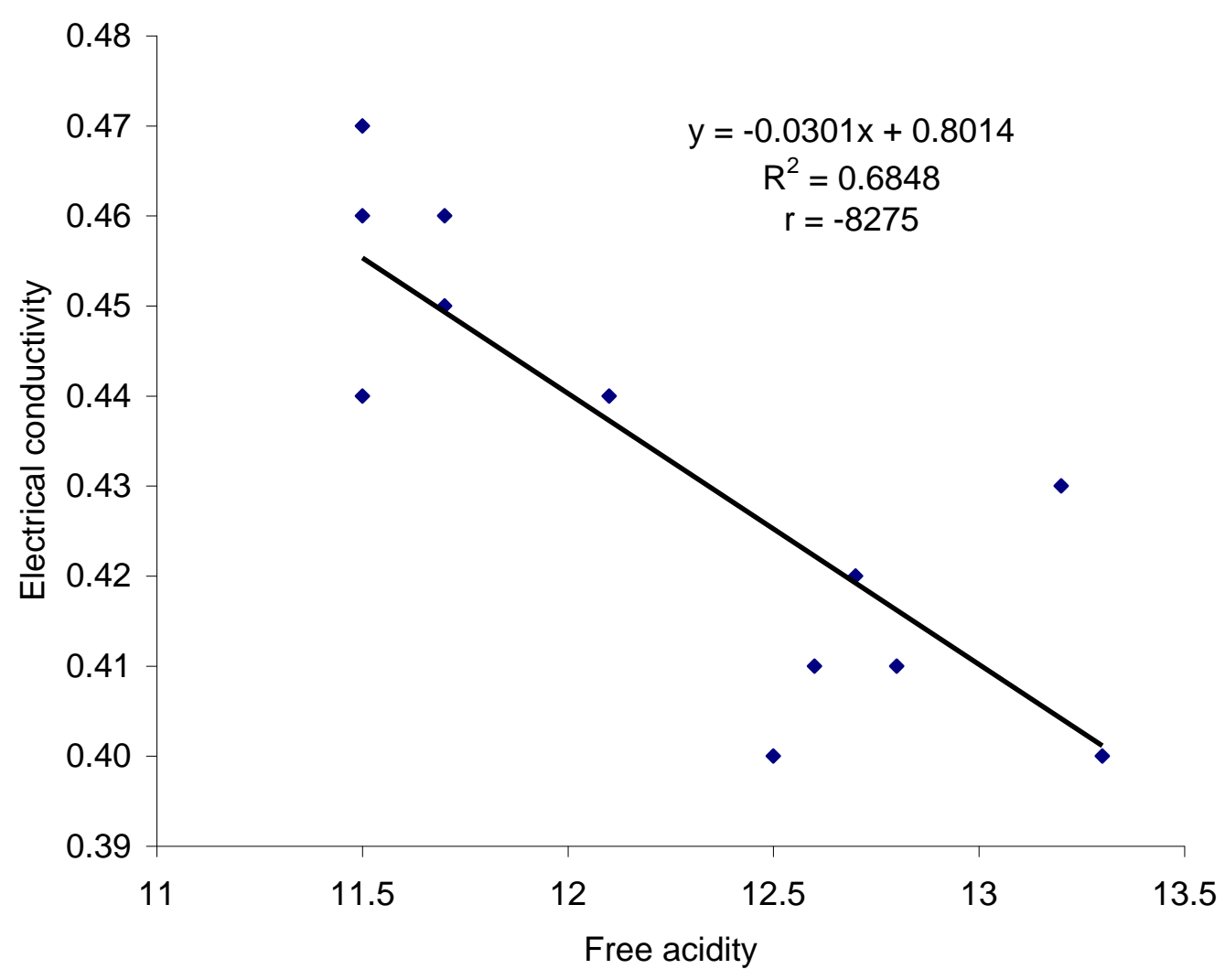

Figure 1: Relationship between free acidity and electrical conductivity of honey harvested in Cross River State. 


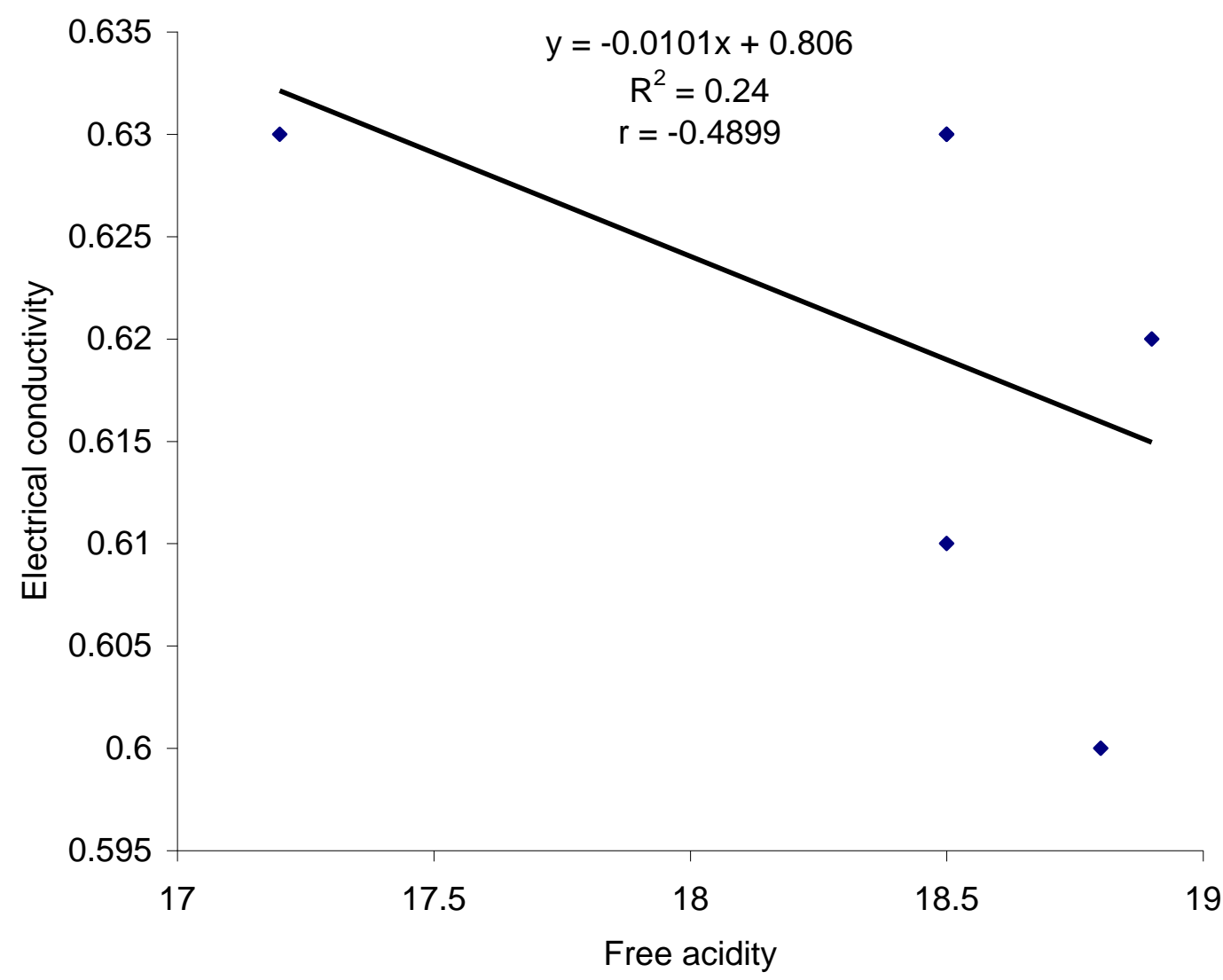

Figure 2: Relationship between free acidity and electrical conductivity of honey harvested in Oyo State.

\begin{abstract}
Discussion
Honey has been used in a variety of ways for centuries. Nutritionally, honey is recently used as an alternative to sucrose as sugar and it is also widely used for industrial purposes. It also serves as a foreign exchange earning where it is widely produced.
\end{abstract}

Table 1 shows the results of the sugar analysis of the honey samples from the two states. The results obtained confirmed that fructose and glucose are the dominant sugars in honey (White and Doner, 1980). Fructose $(\mathrm{g} / 100 \mathrm{~g})$ in all the samples ranged from $28.45 \pm 0.09$ in Obudu wild honey to $36.45 \pm 0.14$ in Obudu farm. It has been reported that honey is rich in reducing sugars (Chaker et al., 2016; El-Sohaimy et al., 2015; Santos et al., 2014; Aloisi, 2012; Fasasi, 2012; Amir et al., 2010 and Caterelli et al., 2008) but low in other sugar components. There is no standard limit to the individual sugars in honey. Honey sample from Obudu farm has the highest fructose and glucose values. There was no significant difference between the fructose and glucose values in the two samples from Oyo state but the values vary significantly in the four samples from Cross River state. Obudu farm also has the highest sum of all sugars in all the samples. The sucrose content of all the samples met the required standard of not more than 5g/100g (European Council 2002). The sucrose content of the samples vary between $0.70 \pm 0.00$ to $1.20 \pm 0.06 \mathrm{~g} / 100 \mathrm{~g}$. The fructose/glucose $(\mathrm{F} / \mathrm{G})$ ratio were $1.27 \pm 0.01,1.24 \pm 0.01,1.32 \pm 0.00,1.41 \pm$ $0.00,1.39 \pm 0.07$ and $1.35 \pm 0.01$ for Igoli in Ogoja, Obudu farm, Agoi Ibami, Obudu wild, Eruwa and Iseyin respectively. $\mathrm{F} / \mathrm{G}$ ratio is an indication of honey quality. It indicates the ability of honey to crystallize since glucose is less soluble in water than fructose (Amir et al., 2010). Honey crystallization is slower when the ratio is more than 1.0 (Draiaia et al., 2015) and faster when it is less than 1.0 (Amir et al., 2010). The $F / G$ ratios in all the honey samples were more than 1.0, which indicates slower crystallization. Crystallization also depends on storage temperature. Obudu farm has the lowest F/G ratio at 1.24 but there 
was no significant difference between the ratios in all the samples studied.

HMF is a representation of the freshness of honey (Cantarell et al., 2008). The HMF value for all the samples ranged from $12.77 \pm 0.29 \mathrm{mg} / \mathrm{kg}$ to $62.60 \pm$ $0.71 \mathrm{mg} / \mathrm{kg}$. Obudu wild honey recorded the lowest mean value of $12.77 \pm 0.29 \mathrm{mg} / \mathrm{kg}$ and Iseyin has the highest of $62.60 \pm 0.71 \mathrm{mg} / \mathrm{kg}$ which is still within the international standard for the tropics $(80 \mathrm{mg} / \mathrm{kg})$ Codex Alimentations (2001). The results obtained for HMF in this study were significantly higher than those reported by Aloisi (2010), Fasasi (2010) and Canterelli et al. (2008). The European Council has set a limit of less than $15 \mathrm{mg} / \mathrm{kg}$ HMF concentration for any honey labeled as virgin. This value can increase as honey undergoes heat treatment to reduce viscosity and prevent crystallization and to facilitate filling (Subramanian et al., 2014). These results indicate that the honey samples in this study meet the standard for virgin honey as indicated by European Council (2002).

Acidity of honey is due to the presence of organic acids and contributes to its characteristic tastes. Values of free acidity $(\mathrm{meq} / \mathrm{kg})$ in this study ranged from $11.57 \pm 0.07$ to $18.60 \pm 0.10$. The values were lower than the allowed limits of $50 \mathrm{meq} / \mathrm{kg}$ (The Council of the European Union, 2002), showing the absence of undesirable fermentation (Yadata, 2014; Eteraf-Oskouei and Najafi, 2013; Adenekan et al., 2010; Aloisi, 2010; Garcia et al., 2001).

Electrical conductivity $(\mathrm{mS} / \mathrm{cm})$ of the honey samples in this study ranged from $0.41 \pm 0.01$ to $0.63 \pm 0.00$. The samples from Oyo state had higher value for electrical conductivity than those from Cross River state. The results were within the range of values reported by Chaker et al. (2016) and Santos et al. (2014). There was a negative correlation between the electrical conductivity and free acidity in all the samples as shown in figures 1 and 2 .

\section{Conclusion}

The sum of fructose and glucose in (Obudu wild) honey presumes that it can be used by diabetic patients as the value is below the $60 \mathrm{~g} / 100 \mathrm{~g}$ recommended by Codex Alimentarius standard. Also, the fructose/glucose ratio for all the samples was more than 1 which indicates slower crystallization. There may be a need for Nigeria to set country specific values for honeys produced in the country as the range in the samples studied, varied widely. Honeys from Igoli and Obudu were within the international standards set by both European Council and Codex Alimentation. Sucrose content for all the honey samples were well within the European Council standard of not more than $5 \mathrm{~g} / 100 \mathrm{~g}$. Total acidity and HMF values showed good indicators of the freshness of the honey samples.

\section{References}

1. Adams, B.A., Osikabor, B, Olomola, A.A and Adesope, A.A.A (2010) Analysis of physical and chemical composition of honey samples in selected markets in Ibadan Metropolis. Journal of Agriculture and Social Research 10(2)

2. Adenekan, M. O., Amusa, N.A., Lawal, A. O and Okpeze, V.E (2010) Physico-Chemical and Microbiological properties of honey samples obtained from Ibadan. Journal of Microbiology and Antimicrobials. 2(8) $100-104$

3. Alosis, P.V. (2010) Determination of quality chemical parameters of honey from Chubut (Argentinean Patagonia). Chilean Journal of Agriculture Research 70(4). 640 - 645

4. Amir, Y., Yesli, A., Bengana, M., Sadoudi, R and Amrouche, T (2010) Physico-Chemical and Microbiological assessment of honey from Algeria. Electronic Journal of Environmental, Agriculture and Food Chemistry 9(9) 1485 - 1494

5. Alvarez-Suarez, J.M., Gasparrini, M., Forbes-Hernandez, L.M and Giamperr, F (2014) The Composition and Biological activity of honey. A focus on Manuka Honey. Journal of Foods. 3; 420 - 432

6. vi(a).AOAC (1999) Official Methods of Analysis. 16th edition. 5th Revision. Vol II. Chapter 44, Sub-chapter 4. Cunnif P. (ed). Washington DC. USA

7. vi(b). AOAC (2000) Sugars and Sugar products. In: Official Methods of Analysis. Horowitz, W. (ed). Association of Official Analytical Chemists International, vol. 2(44), 16th edition. Washington. DC. $22-33$

8. Ball, D. W. (2007) The chemical composition of Honey, Journal of Chemical Education 84(10): 1643 - 1646

9. Bogdanov, S and Baumann (1988) Bestimmung von Honigzucker Mtch HPLC. Mitt Geblebensm Hygine 7a, 198 $-206$

10. Bodganov, S., Martin, P., Lullman, C., Borneck R., Flamini, Ch., Morlot, M., Heretier, J., Vorurohl, G., Russman, H., Persano-Oddo, L., Sabatini, A.G., Marcazzan, G.L., Marioleas, P., Tsigouri, K., Kerkvliet, J., Ortiz, A. and Ivanov, T. (1997) Harmonized methods of the European Honey Commission. Apidologie (extra issue) $1-59$

11. Bogdanov, S., Ruoff, R. and Persano-Oddo, L. (2004), Physicochemical methods of the characterization of unifloral honeys: A review. Apidologie 35: $4-17$

12. Bogdanov, S. (2009) Honey Composition. In: Book of Honey, Chapter 5, Bee Product Science.

13. Buba, F., Gidado, A. and Shugaba, A. (2013). Analysis of chemical composition of Honey samples from North-East Nigeria. Biochemistry and analytical Chemistry. 2(139)

14. Canterelli, M.A., Pellerano, R.G., Marchevsky, E.J. and Camina, J.M. (2008). Quality of Honey from Argentina. Study of chemical composition and trace elements. Journal of the Argentine Chemical Society: 96(1-2), $33-41$

15. Chaker, A., Ramane, A., Marcazzah, G.L. and Ferrazi, P. (2016). Physicochemical properties of some honey produced from different plants in Morocco. Arabian Journal of Chemistry. 9(2) $946-954$

16. Codex Alimentations (2001) Draft Revised Standard for honey (at step 10 of the Codex Procedure) Alinorm 01(25) 19 $-26$

17. Dike, O. N. and Onwuka, E. (2016) Entrepreneur Perception and Growth of Beekeeping in Abia State. Nigeria. International Journal of Physical and Human Geography. 4(3) $1-11$

18. Downey. G., Hussey, K., Kelly, J.D., Walshe, T.F. and Martin, P.G. (2005) Preliminary contribution to the characterization of artisanal honey produced on the Island of Ireland by palynological and physicochemical data. Food Chemistry, 91: 347 - 354

19. Draiaia, R., Chefrour, A., Dainese, N., Borin, A., Manzinello, C., Gallina, A. and Mutinelli, F. (2015) Physico-Chemical parameters and antibiotics residuals in Algerian honey. African Journal of Biotechnology 14(14) 1242 - 1251

20. Eteraf-Oskouei, T. and Najafi, M. (2013) Traditional and Modern Uses of Natural Honey in Human Diseases: A Review. Iranian Journal of Basic Medical Sciences. 16(6): $731-742$ 
21. El-Metwaly, A.A.E. (2015) Factors affecting the physical and chemical characteristics of Egyptian Beehoney. Ph.D Thesis. Faculty of Agriculture. Cairo University, Cairo. Egypt. 320p

22. El-Sahaimy, S.A., Masry, S.H.D. and Shehata, M.G. (2015). Physicochemical characteristics of honey from different origins. Annals of Agricultural Sciences: 60(2), 279 - 287

23. European Union Council (2002) Council direction 2001/110/EC of 20 December 2001 relating to Honey. Official Journal of European Communities L. 10: 47 - 52

24. Ezekiel, A.A., Olagunju, F.I. and Olapade-Ogunwole, F (2013). Economics of Honey production in Oyo State, Nigeria. Global Advanced Research. Journals of Arts and Humanities. Vol 2(2): $43-47$

25. Fasasi, K.A. (2012) Physicochemical attributes of Nigerian natural honey from honey bee (Apus mellifera adansonii) (Hymenoptera Alpedea) and its shelf life in storage at room temperature. Pakistan Journal of Biological Sciences. 15: $1027-1033$

26. Garcia, M.C., Perez, A.C. and Harrara, A. (2001). Pollen analysis and antibacterial activity of Spanish Honeys. Food Science Technology International 7: 155 - 158

27. Human Metabolic Database http://hmdb.ca/metabolites/HMDB11742.

(2007). 03/03/2009, updated 02/03/2017, cited 19/06/2017
28. Kamal, M.A. and Klein, P. (2010). Determination of sugars in honey by liquid chromatography. Saudi Journal of Biological Sciences. Vol 18(1), $17-21$

29. Santos, E.K.G., Filho, A.N.D., Leite, R.H.L., Aroucha, E.N.M., Santos, A. G. and Oliveira, T.A. (2014) Rheological and some physico-chemical characteristics of some floral honey from plants of Caatinga. Anais da Academia Brasileira de Ciencias. 86(2)

30. Subramanian, R., Umesh Hebbar, H. and Rastogi, N.K. (2007) Processing of Honey: A review. International Journal of Food Properties. 10(1): $127-143$

31. Terrab, A., Diez, M.J. and Heredia, F.J. (2003) Palynological, physico-chemical and colour characterization of Moroccan honey: Orange (Citrus spp) honey. International Journal of Food Science and Technology, 38: 387 - 394

32. White, J.W. and Doner, L.W. (1980) Honey composition and properties of beekeeping in the United States. Agriculture Handbook number 335: $82-91$. Published by the Science and Education Administration. Eastern Regional Research Centre. Philadelphia. USA

33. Yadata, D. (2014) Detection of the electrical conductivity and acidity of honey from different areas of Tepi. Journal of Food Science and Technology. 2(5): 59 - 63. 